\title{
Effects of Indole Acetic Acid (IAA) and Indole Butyric Acid (IBA) to The Growth and Rooting of Ironwood (Eusideroxylon zwageri Teijsm. \& Binn.) Air Layering
}

\author{
Bambang Irawan", Rike Puspitasari Tamin, Rizky Ayu Hardiyanti \\ Faculty of Forestry, University of Jambi \\ Campus Pinang Masak, Jambi-Muara Bulian Main Road, KM. 15 Mendalo Darat-Jambi, Indonesia 36361
}

Received April 1, 2019/Accepted August 14, 2019

\begin{abstract}
Due to over exploitation, the population of Eusideroxylon zwageri is decreasing drastically. One simple technique to conserve the last remaining genetic resources of E. zwageri is by air layering. The experiment was divided into two. The experiment was conducted from July 2018 to February 2019. The first experiment was conducted using branches that grew from coppices while the second experiment using twigs that grew from normal adult trees. Randomized Block Design was applied with three replicates. The treatments were consisted of nine concentration of auxin namely 0 ppm of auxin; 1,000 ppm; 1,500 ppm; 2,000 ppm, and 2,500 ppm of IAA and 1,000 ppm;2,000 ppm; 3,000 ppm and 4,000 ppm of IBA. The result of experiment shows that the IBA growth regulator seems to be more effective in regulating growth and rooting of E. zwageri air layering compared to IAA. Results for air layering which was taken from coppices revealed that 1,000 ppm of IBA obtained the best results. Air layering of branches taken from coppice is possible even without any additional growth regulator. While, air layering of twigs which was taken from normal trees revealed that the best treatment is 3,000 ppm of IBA.
\end{abstract}

Keywords: air layering, E. zwageri, Indole Acetic Acid, Indole Butyric Acid

*Correspondence author, email: irawanbam@yahoo.com

\section{Introduction}

Bulian/ulin/belian/borneo ironwood (Eusideroxylon zwageri Teijsm. \& Binn.), synonym to Bihania borneensis Meissner and Eusideroxylon lauriflora Auct. E. zwageri, is one member of the Lauraceae, tribus of Cryptocaryeae and subtribus of Eusideroxylineae (Kostermans, 1957). Natural distribution of $E$. zwageri is limited to the east until Borneo and to the west until west coast of West Sumatera; to the North is not more than $\mathrm{N}^{\circ}$ and to the south is until $\mathrm{S}^{\circ}$ (Heyne, 1927). In Borneo, E. zwageri grows almost in all parts of Borneo forests including Sarawak and Brunei. In South and Southeast Sumatera, it is distributed in Palembang, Bangka, Belitung, Jambi, Bengkulu, Siak, and Indragiri. E. zwageri also can be found in Lampung, the southern part of West Sumatera and Sijunjung. In Philippines, it can be found in forests of Tawi-Tawi Island which is belonged to Sulu archipelago (Beekman, 1949).

E. zwageri grows well in the humid climate and it also able to grow in the places with short dry season (Koopman \& Verhoef, 1938). Soedibja (1952) reported that in immature stage, E. zwageri is a shade bearer species. It especially found on sandy soil and requires a fairly drained soil with a wet climate. Additionally, Soerianegera (1974) reported that $E$. zwageri could be found in the areas with dry sub-humid climate and humid climate with precipitation from 2,000 to $6,000 \mathrm{~mm}_{\text {year }}{ }^{-1}$.
The timber of E. zwageri is used for making furniture, which produced black brownish and furniture, window and door frames, harbors, heavy construction, roofs, bridges, railway sleepers, marine pilling, boat construction, fence and house posts, heavy duty industrial flooring, tool handles, talisman, jewelers, bridges, and shingles, which are produced only by wood which has high splitability. Heyne (1927) reported that E. zwageris' seeds can be used as medicine against swelling. Kostermans et al. (1994) reported the fruits are poisonous and pulverized which have been used by local people medicinally against swelling. Local people in Senami, Jambi also used the seeds as medicine (Irawan 2005). Traditionally, local people used $E$. zwageri wood that immersed in the water to relieve toothache which lead to idea that this wood possibly contain several chemical substances that have antibiotic effects or the wood just contain substances that have analgesic effects. Early investigation found that E. zwageris' wood contains several chemical substances from group of alkaloid, flavonoid, triterpenoid, tanin, and saponin. Flavonoid, triterpenoid, and saponin are chemical substances that have potency as antibacterial and antivirus (Robinson 1995). Additionally, E. zwageris' wood empirically proofed that has chemical substances that was able to control bacteria especially Staphylococcus aureus. The study confirmed antibacterial property of $E$. zwageris' wood extract and concluded that the minimal inhibitor 
concentration (MIC) of the extract was 2\% (Ajizah et al., 2007).

E. zwageri is one of the most renowned timbers of Borneo. It has been favored both for local use and export trade. Over-exploitation together with forest clearance has led to the decline of this slow-growing timber species. The increased availability of forest roads opened by concessionaires is leading to greater problems of uncontrollable exploitation in Kalimantan (Partomihardjo, 1987).

Oldfield et al. (1998) showed that E. zwageri is included in the list of threatened tree species. Its decline was first noted in 1955. Overexploitation and shifting agriculture had been noted in Kalimantan, Sumatera, Sabah, Sarawak, and the Philippines considered as the main factors for decreasing population of $E$. zwageri in its natural habitat. The regeneration of $E$. zwageri in logged forests is limited. The $E$. zwageri has only been planted on a small scale due to the limited supply of seeds and seedlings. Based on the IUCN red list of threatened species, E. zwageris' category and criteria are $V U A l c d+2 c d$. This means that $E$. zwageri is not critically endangered or endangered but is facing a high risk of extinction in the wild in the medium-term future (IUCN, 2019).

Over-exploitation, shifting cultivation, and extensive road systems by the timber industry, selective logging, and developing infrastructures were the major threats to $E$. zwageri (Peluso, 1992; Kostermans et al., 1994). WWF (2001) reported that land clearing for plantations and agriculture as well as logging had been heavy occurred in the lowlands east of the Bukit Barisan Range, mainly during the 1998-1999 economic crisis. Extensive stands of E. zwageri have been almost entirely destroyed in southern Sumatera.

One example of the degradation of $E$. zwageri forest is Senami forest, Jambi. The degradation is very clear from the comparison of E. zwageri volume in 1919, 1983, and the results of research in 2004. Irawan (2005), who conducted research in 2004, obtained that the volume of E. zwageri was only $5.18 \mathrm{~m}^{3} \mathrm{ha}^{-1}$. Masano and Omon (1983) who doing research in the same location found significantly different figures where the volume for undisturbed forest was $120.9 \mathrm{~m}^{3}$ $\mathrm{ha}^{-1}$ while for over-logged area was $56.45 \mathrm{~m}^{3} \mathrm{ha}^{-1}$. Another research conducted by Gresser (1919) also in Senami forest, found that the average volume was $105.6 \mathrm{~m}^{3} \mathrm{ha}^{-1}$.

One interesting characteristic of E. zwager $i$ is its ability to coppice. Field data shows that all of E. zwageri stumps produce coppices (Irawan, 2005). The number of coppices produced by $E$. zwageri seems to not be influenced by the diameter size of the stump (Irawan \& Gruber, 2004; Irawan, 2005). Ecologically, sprouting is very important for the survival of $E$. zwageri species since this species faces over exploitation. About $65 \%$ out of plots where E. zwageri can be found was also obtained coppicing stumps. It indicates that the important of coppices is not only for survival of individual tree but also important for the forest stand dynamic (Putz \& Brokaw, 1989; Kammesheidt, 1998; Miura \& Yamamoto, 2003).

Many researchers reported that the growth rate of $E$. zwageri is very slow for mature as well as juvenile stage (Beekman, 1949; Kostermans et al., 1994; Kiyono \& Hastaniah, 2000; Irawan, 2005). By coppicing, the growth rate of $E$. zwageri can be increased. Coppices may grow three times faster for the diameter and 5.6 times for the height compared to growth rate of E. zwageris' seedlings. Fiveyear-old coppices can reach diameter between $4 \mathrm{~cm}$ to $9 \mathrm{~cm}$ depend on the varieties of E. zwageri.

The growth rate of coppices that much faster compared to seedlings is confirmed by local people. The explanation for this phenomenon was explained by some reports the coppices mostly have received better supports of sufficient nutrients and water from the well-developed root systems. In contrast, the root systems of the seedlings which develop simultaneously with the growth of the trees (Beekman, 1949; Irawan, 2002; Miura \& Yamamoto, 2003).

The coppices are not only important for the survival of the trees and maintaining stand dynamic but also could be used as propagation materials (Beekman, 1949; Irawan, 2001). Directly, the coppices can be taken as cutting materials or as hedge orchards. Preliminary research showed that sprouts can be used as cutting materials, however the results were not good enough yet (Irawan, 1999). Another method is to utilize coppices for air layering propagation.

Based on the present status of E. zwageri as explained before, it is remarkably urgent to conserve and develop the remaining genetic resources of $E$. zwageri. Without any truly effort on conservation and development, the loss of genetic resources will be continued and forever. One simple but useful technique to save the last remaining genetic resources of $E$. zwageri is by air layering propagation since it will produce identical trees. The air layering technique also can be utilized for developing clonal seed orchard since it will produce identical mother trees that able to flowering and fruiting quite early with dwarfed trees (Irawan, 2018).

The preliminary experiment revealed that the air layering of E. zwageri can be conducted without any additional growth regulator but the root formation took place quite long time. It needs about six to eight months (Irawan, 2018). Nuraini et al. (2017) reported that there was no interaction between concentration of auxin and method on cambium scarifications on air layering propagation of E. zwageri. While, the treatment of $750 \mathrm{ppm}$ of Indole Acetyc Acid (IAA) obtained the best results. Almost the same concentration of IAA also provided the best results for cutting of $E$. zwageri that was $700 \mathrm{ppm}$ (Irawan et al., 2011). However, there was an indication that applying till 1.000 ppm of IAA still increased the percentage of rooted branches that propagated by air layering. The percentage of rooted branches propagated by air layering reached to $62.92 \%$ due to treatment of 1,000 ppm IAA (Nuraini et al., 2017). The number of this rooted air layering is higher compared to percentage of rooted branches that propagated by air layering reported by Diantina (2008) that was only $37.50 \%$.

Another growth regulator under auxin that also potentially used for triggering rooting is Indole Butyric Acid (IBA). The IBA was reported to be efficiently triggering the rooting system of cutting of $E$. zwageri (Irawan, 1999; 2001; Utami et al., 2005; Irawan et al., 2011). Irawan et al. (2011) reported that 2,250 ppm and 3,000 ppm of IBA provided the best rooting on cutting of $E$. zwageri. This result confirmed the experiment results before that concentration of IBA from $1,500 \mathrm{ppm}$ to $3,000 \mathrm{ppm}$ provided the best result on cutting of 
E. zwageri (Irawan, 1999; 2001). Utami et al. (2005) reported that the treatment of IBA $10 \mathrm{mg} \ell^{-1}$ of IBA obtained the best result on cutting of $E$. zwageri. While the combination of 10 $\mathrm{mg} \ell^{-1}$ IBA and $50 \mathrm{mg}^{-1}$ of $\mathrm{C}$ Vitamin also provided the best rooting of cutting of $E$. zwageri both on root number and root length.

Some of research results revealed that IAA had positive effects on E. zwageris' propagation especially on cutting and air layering. Irawan $(1999 ; 2001)$ reported that IAA had better effect on rooting and growth of $E$. zwageris' cutting compared to effects of IBA. The best concentration of IAA was $500 \mathrm{ppm}$ while the best concentration of IBA was 1,500 $\mathrm{ppm}$ and 3,000 ppm. Another research also confirmed almost the same results as reported by Irawan et al. (2011) that 700 ppm of IAA provided the best results on one and two nodes of E. zwageris' cuttings. While 2,250 ppm and 3,000 ppm of IBA provided the best cutting results compared to other concentration of IBA.

\section{Methods}

The experiment was conducted for eight months from July 2018 to February 2019. The experiment was conducted on Sultan Thaha Syaifuddin (STS) Grand Forest, Batanghari District, Jambi Province. The STS Grand Forest was stated based on Decree of Forestry Ministry Number 94/KptsII/2001 with the size of 15,830 ha.

Experimental design The experiment was divided into two main experiment but related one to another. The first experiment was conducted using the branches that grow from coppice while the second experiment was conducted using twigs that grow from a normal adult tree. The utilization of coppices was based on the recommendation of early publications before (Irawan \& Gruber, 2004; Irawan, 2005; Irawan et al., 2011; Irawan, 2018).

Randomized Block Design was applied for both experiments with three replicates. The block was determined based on the position of the branches in the coppice for the first experiment while for the second experiment, the block was based on the position the twigs on the branches of the mother trees. The treatments were consisted of nine concentration levels of auxin namely 0 ppm of auxin; 1,000 ppm, 1,500 ppm, 2,000 ppm, and 2,500 ppm of IAA and 1,000 ppm, 2,000 ppm, 3,000 ppm, and 4,000 ppm of IBA. The concentration levels of auxin that tested were formulated based on earlier research results (Irawan, 2001; Irawan et al., 2011; Nuraini et al., 2017). The total number of experimental units was 27 for each experiment while the number of branches that propagated was five. Therefore, total number of air layering was 135 for each experiment.

The media that used for the air layering was top soil, sand, and organic matter with the comparison of 1:1:1 (Irawan, 2005). The amount of media for each air layering branch was $150 \mathrm{~g}$. The media was put in the transparent plastic with 5 holes on each side. The size of selected branches was about $0.6 \mathrm{~cm}$ to $1.0 \mathrm{~cm}$ in diameter. The cutting area size for removing the bark was about $3 \mathrm{~cm}$ with the starting cut at 5 $\mathrm{cm}$ from the branch or twig base. The thin layer of cambium was removed then the auxin was applied using brush evenly at the tip part of the cutting area.
The tending of the air layering branches was done regularly including watering that applied mostly once a day except during rainy day and fertilizing that applied once a month. The fertilizer that used was liquid fertilizer that consisted of $20 \%$ of nitrogen, $15 \%$ of phosphate $\left(\mathrm{P}_{2} \mathrm{O}_{5}\right), 15 \%$ of potassium $\left(\mathrm{K}_{2} \mathrm{O}\right)$, and $1 \%$ of magnesium $\left(\mathrm{MgSO}_{4}\right)$. The concentration of application was $3 \mathrm{~g}^{-1}$.

Parameters and statistical analysis These parameters included: percentage of life air layering branches (\%), percentage of rooted air layering branches $(\%)$, shoot length $(\mathrm{cm})$, stem diameter $(\mathrm{cm})$, leaf area $\left(\mathrm{cm}^{2}\right)$, and shoot number. The data were subjected to statistical analysis: a one-way Analysis of Variance (Anova) with variety as a factor. The statistical test for all components of variance was determined at 0.05 significance level of Duncan Multiple Range Test (Gomez \& Gomez, 1984). The $t$-test was applied to find the correlation between rooted air layering branches with shoot length.

\section{Results and Discussion}

The $\mathrm{F}$ values of four different parameters of branches of E. zwageri that propagated by air layering as results of different levels of auxin concentration at eight months after treatment was presented on Table 1 . Table 1 shows that three parameters of air layering which was taken from coppices are highly significant different. Those parameters are shoot length and shoot number as well as percentage of rooted air layering. Meanwhile, only two parameters of air layering which was taken from normal trees are significantly different, namely shoot number and percentage of rooted air layering. Among those four parameters, the percentage rooted air layering is the most important parameter.

Table 2 shows that all parameters of air layering taken from coppice is significantly different among treatments. Overall results revealed that 1,000 ppm of IBA obtained the best results compared to other treatments. However, in the most parameters, the $1,000 \mathrm{ppm}$ of IBA is not significantly different to control (without additional growth regulator) and $2,000 \mathrm{ppm}$ of IBA. The most interesting result on air layering of branches taken from coppice is that without any additional growth regulator to the air layering propagation is also still possible. The results air layering of without growth regulator still provided high percentage rooted air layering with the mean value of $46.67 \%$. This value is not significantly different to the best performed treatment. Some other reports also confirmed that growth regulator was not always needed for tree vegetative propagation. Mulyani et al. (1999) reported that the effect of hormone was not significantly different on the shoot growth of hypocotyl cutting of Rhizophora mucronata.

Table 3 shows that 3,000 ppm of IBA obtained the best results on air layering of twig which were taken from normal trees compared to other treatments for all parameters. Even, this treatment is not significantly different to $2,500 \mathrm{ppm}$ of IAA, 1,000 ppm and 2,000 ppm of IBA on rooted air layering but numerically, the value is much higher. The percentage of rooted air layering by 3,000 ppm of IBA was $40 \%$ while those other treatment only provided the percentage of rooted air layering with the value of $26.67 \%$. 
Table 1 The $F$-values of four different parameters of branches of Eusideroxylon zwageri that propagated by air layering as a result of different levels of auxin at eight months after treatment

\begin{tabular}{lcc}
\hline \multirow{2}{*}{ Parameter } & \multicolumn{2}{c}{$F$-value } \\
\cline { 2 - 3 } & Branches from coppices & Twig from normal trees \\
\hline Shoot length & $30.74^{* *}$ & 1.75 \\
Shoot number & $7.42^{* *}$ & $2.83^{*}$ \\
Percentage of life air layering branches & 2.52 & 1.68 \\
Percentage of rooted air layering branches & $8.70^{* *}$ & $3.63^{*}$ \\
\hline
\end{tabular}

Table 2 Mean values of four traits of Eusideroxylon zwageri Teijsm. \& Binn. branches which was taken from coppices propagated by air layering at eight months after treatment

\begin{tabular}{|c|c|c|c|c|}
\hline Treatments & Shoot length $(\mathrm{cm})$ & Shoot number & Life air layering $(\%)$ & Rooted air layering $(\%)$ \\
\hline $0 \mathrm{ppm}$ auxin & $14.65 \mathrm{ab}$ & $2.86 \mathrm{~b}$ & $73.33 \mathrm{ab}$ & $46.67 \mathrm{ab}$ \\
\hline $1,000 \mathrm{ppm}$ of IAA & $18.06 \mathrm{ab}$ & $3.93 \mathrm{~b}$ & $80.00 \mathrm{ab}$ & $20.00 \mathrm{bc}$ \\
\hline $1,500 \mathrm{ppm}$ of IAA & $9.77 \mathrm{~b}$ & $1.53 \mathrm{~b}$ & $53.33 \mathrm{~b}$ & $13.33 \mathrm{c}$ \\
\hline $2,000 \mathrm{ppm}$ of IAA & $20.43 \mathrm{ab}$ & $3.06 \mathrm{~b}$ & $73.33 \mathrm{ab}$ & $26.67 \mathrm{bc}$ \\
\hline $2,500 \mathrm{ppm}$ of IAA & $13.24 \mathrm{~b}$ & $2.20 \mathrm{~b}$ & $80.00 \mathrm{ab}$ & $6.67 \mathrm{c}$ \\
\hline $1,000 \mathrm{ppm}$ of IBA & $29.74 \mathrm{a}$ & $4.73 \mathrm{ab}$ & $100.00 \mathrm{a}$ & $60.00 \mathrm{a}$ \\
\hline $2,000 \mathrm{ppm}$ of IBA & $21.55 \mathrm{ab}$ & $3.73 \mathrm{~b}$ & $93.33 \mathrm{ab}$ & $46.67 \mathrm{ab}$ \\
\hline $3,000 \mathrm{ppm}$ of IBA & $10.29 \mathrm{~b}$ & $5.80 \mathrm{ab}$ & $100.00 \mathrm{a}$ & $26.67 \mathrm{bc}$ \\
\hline $4,000 \mathrm{ppm}$ of IBA & $9.73 \mathrm{~b}$ & $8.80 \mathrm{a}$ & $100.00 \mathrm{a}$ & $6.67 \mathrm{c}$ \\
\hline
\end{tabular}

Table 3 Mean values of four traits of Eusideroxylon zwageri Teijsm. \& Binn. branches which was taken from normal trees propagated by air layering at eight months after treatment

\begin{tabular}{ccccc}
\hline \multicolumn{1}{c}{ Treatments } & Shoot length $(\mathrm{cm})$ & Shoot number & Life air layering (\%) & Rooted air layering $(\%)$ \\
\hline 0 ppm auxin & $10.72 \mathrm{~b}$ & $6.46 \mathrm{~b}$ & $60.00 \mathrm{~b}$ & $13.33 \mathrm{bc}$ \\
$1,000 \mathrm{ppm}$ of IAA & $5.35 \mathrm{~cd}$ & $2.53 \mathrm{bc}$ & $60.00 \mathrm{~b}$ & $0.00 \mathrm{c}$ \\
$1,500 \mathrm{ppm}$ of IAA & $9.20 \mathrm{bc}$ & $2.00 \mathrm{bc}$ & $46.67 \mathrm{~b}$ & $0.00 \mathrm{c}$ \\
$2,000 \mathrm{ppm}$ of IAA & $4.78 \mathrm{~cd}$ & $2.33 \mathrm{bc}$ & $60.00 \mathrm{~b}$ & $0.00 \mathrm{c}$ \\
$2,500 \mathrm{ppm}$ of IAA & $6.57 \mathrm{bc}$ & $2.60 \mathrm{bc}$ & $60.00 \mathrm{~b}$ & $26.67 \mathrm{ab}$ \\
$1,000 \mathrm{ppm}$ of IBA & $6.94 \mathrm{bc}$ & $2.66 \mathrm{bc}$ & $66.67 \mathrm{~b}$ & $26.67 \mathrm{ab}$ \\
$2,000 \mathrm{ppm}$ of IBA & $1.29 \mathrm{~d}$ & $0.46 \mathrm{c}$ & $46.67 \mathrm{~b}$ & $26.67 \mathrm{ab}$ \\
$3,000 \mathrm{ppm}$ of IBA & $30.34 \mathrm{a}$ & $14.80 \mathrm{a}$ & $100.00 \mathrm{a}$ & $40.00 \mathrm{a}$ \\
$4,000 \mathrm{ppm}$ of IBA & $4.69 \mathrm{~cd}$ & $2.33 \mathrm{bc}$ & $66.67 \mathrm{~b}$ & $20.00 \mathrm{bc}$ \\
\hline
\end{tabular}


The shoot length and shoot number of air layering are two parameters that are closely related. Both parameters are significantly different among treatments. For air layering which were taken from the coppice as presented on Table 2, the best shoot length was provide by $1,000 \mathrm{ppm}$ of IBA with the value of $29.74 \mathrm{~cm}$ but the result of this treatment is not significantly different to results obtained by $2,000 \mathrm{ppm}$ of IAA dan 2,000 ppm of IBA. Meanwhile for shoot number, the best result was provided by treatment of $4,000 \mathrm{ppm}$ of IBA with the value of $8.80 \mathrm{~cm}$ but this result is not significantly different results obtained by to $1,000 \mathrm{ppm}$ and $3,000 \mathrm{ppm}$ of IBA. The shoot length and shoot number of air layering taken from normal trees also significantly among treatments. The best treatment for shoot length was provided by 3,000 ppm of IBA. The result of this treatments is significantly different to results of other treatments.

The shoot has an important role as a place of leaves while the most important function of leaves is to conduct the photosynthesis process. During photosynthesis, leaves convert inorganic materials to organic compounds using energy from sunlight. Those organic compounds are the main sources of energy for organ development. The leaf parameter, especially total leaf area, is the most important parameter that influences photosynthesis rate (Ceulemans \& Saugier, 1991; Hari et al., 1991). Furthermore, Kirschbaum (2011) explained that increasing photosynthesis increases carbon availability for plants. However, some limiting factors especially nutrient availability will determine the increasing growth due to increasing photosynthesis.

The percentage of life air layering is also significantly different among treatments. However, the trend between air layering taken from coppices and from normal trees is slightly different. The treatment of $1,000 \mathrm{ppm}, 3,000 \mathrm{ppm}$, and 4,000 ppm of IBA provided the highest value of life layering percentage with the value of $100 \%$. The results of those treatments are significantly different to result of 1,500 ppm of IAA but they are not significantly different to other treatments. While for air layering which was taken from normal trees, the best result was provided by $3,00 \mathrm{ppm}$ of IBA. The result of this treatment is significantly different to results of other treatments.

Table 2 and Table 3 show that the percentage of rooted air layering among treatments is significantly different one to another. The best result on percentage of rooted air layering which was taken from coppice trees was obtained by treatment of $1,000 \mathrm{ppm}$ IBA. This result is not significantly different to results of control (without growth regulator) and 2,000 ppm of IBA. While, the best result on percentage of rooted air layering which was taken from normal trees was obtained by treatment of 3,000 ppm IBA. This result is not significantly different to results of $2,500 \mathrm{ppm}$ of IAA, 1,000 ppm of IBA, and 2,000 ppm of IBA.

The result of experiment shows that the IBA growth regulator seems to be more effective in regulating growth and rooting of $E$. zwageri air layering for both air layering resources compared to IAA. This result is contrary to research results on cutting of $E$. zwageri before as reported by Irawan (2001) that IAA had better stimulating ability on rooting and growth of E. zwageri cutting compared to IBA. Nuraini et al. (2017) also reported that IAA with the concentration of $750 \mathrm{ppm}$ provided the best result on propagation of $E$. zwageri using air layering even there was an indication that the concentration of IAA till $1,000 \mathrm{ppm}$ still increased the percentage of rooted air layering.

However, many other researchers also provided another knowledge that IBA is an effective growth regulator for stimulating root system on cutting propagation. Salisbury and Ross (1995) stated that IBA is the most common gowth regulator applied for tree propagation by cutting. This results also confirmed previous study that the concentration of IBA between 1,500-3,000 ppm and 500 ppm of IAA obtained the best result for ironwood cutting (Irawan 1999; 2001).

Utami et al. (2005) reported that statistically there was no interaction among treatment on cutting, IBA concentration, and vitamin $\mathrm{C}$ to the shoot cutting of E. zwageri. The additional IBA with the concentration of $10 \mathrm{mg} \ell^{-1}$ provided better results to the shoot cutting of E. zwageri compared to

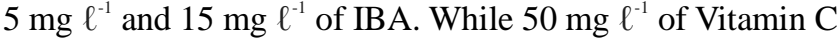
provided best result compared to other concentrations of vitamin $\mathrm{C}$. The cuttings tended to form more root number and root length after treatment of $50 \mathrm{mg} \ell^{-1}$ of vitamin $C$. The

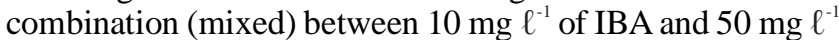
of vitamin $\mathrm{C}$ was the best combination that produced the longest and the most root number compared to other treatments.

The optimal concentration of IBA for rooting was varied for different species. Concentration of $30-40 \mathrm{mg} \ell^{-1}$ IBA obtained $70 \%$ of rooting of teak (Tectona grandi) cutting (Wibowo et al., 2000). Cutting of damar (Agathis loranthifolia Salisb.) required IBA with the concentration of only $100 \mathrm{ppm}$ for providing the best rooting performance (Danu et al., 2011) while for Podocarpus blumei cutting needed until 4,000 $\mathrm{mg}^{-1}$ IBA for performing $80 \%$ rooting (Utami et al., 2005). High concentration of IBA also needed for rooting of Rosa centifolia cutting where, 3,500 ppm IBA performance the best root length and root number (Al-Sagri \& Alderson, 1996).

Tchoundjeu and Leakey (1996) reported IBA was effectively improved rooting system on african mahagony cutting. Their result revealed that the best concentration of the IBA was found to be $200 \mu \mathrm{g}$ per cutting. This concentration increased the percentage of rooted cuttings and increased the number of roots per cutting. The same result also indicated by our study. There were some variations on rooting ability of cutting that treated by the same concteration of IBA. Aminah et al. (1997) reported that IBA application to the cuttings may have an indirect influence by enhancing the translocation speed and carbohydrates movement from top to the base of cuttings. This process consequently stimulates rooting.

Table 4 shows that the results of $t$-test on the comparison between air layering results from the ranches that grow from coppices and twigs from the normal trees. There is not significantly different on the results of air layering propagation that taken from branches of coppices and twigs of normal trees both percentage of life air layering and percentage of rooted air layering. Even the overall mean values of the air layering taken from coppices much higher compared to air layering taken from normal trees on both parameters. The overall mean values of percentage of life air layering taken from coppices was $83.70 \%$ while percentage of life air layering taken from normal trees was $62.98 \%$. The overall mean values of percentage of rooted air layering taken 
from coppices was $28.15 \%$ while percentage of rooted air layering taken from normal trees was $17.04 \%$.

Numerically, the result of this researches indicated that the air layering that taken from coppices tend to provide better results of air layering which were taken from twigs of normal trees even, based on the statistical analysis that the results of both were not significantly different. Those results seem due to the different maturation stage of both materials of air layering where the coppices have younger maturation stage compared to normal trees. As explained by Kleinschmit and Svolba (1988) that the maturation or ageing is one of the most problem of vegetative regeneration. Hendromono et al. (1996) also reported that the rooting ability of cutting of meranti (Shorea spp.) is decreasing with the increasing of the age of cutting materials. This phenomenon was not only for one species but tree species of shorea namely Shorea selanica, S. Leprosula, and S. pinanga. The same result also reported by Ofori et al. (1997) that conducted research on Milicia excelsa cutting.

Ofori et al. (1997) who conducted research on M. excelsa reported that rooting ability tended to decline with increasing age of the ortet. A negative correlation was observed between age of the donor tree and rooting percentage. The effect of treatment on final rooting percentage was highly significant overall, although there was not significant differences in rooting were observed among cuttings from the 4-years-old and those of 1- and 20-years-old stockplants.

Heavy pruning to form new coppices is one method that can be applied to reduce ageing problem both for Hardwood and Conifer (Kleinschmit \& Svolba, 1988). Bolstad and Libby (1982) reported that hedging that including serial pruning on the mother trees or hedge orchards proven to reduce the ageing problem. The result of this research also confirmed the results of other researches before that coppices is not only important for recovery of logged trees but also can be utilized as propagation materials (Beekman, 1949; Irawan, 2001).

The correlation between selected parameters that observed had been tested to understand the degree of correlation between them. The Pearson correlation between shoot length and percentage of rooted air layering for air layering which was taken from coppices is significantly different (Table 5). While, the Pearson correlation between shoot length and percentage of rooted air layering for air layering which was taken from normal trees is not significantly different. It indicates that the growth of shoot will influence the root formation. As explained before, that the shoot length has correlation with the photosynthetic activity.

The relationship between shoot length and success on rooting of air layering propagation has not been reported yet. However, the correlation between cutting length and rooting ability had been reported by many studies. The effects of the cutting length on rooting in many studies was varied. Ofori et al. (1997) reported that there is no significant effect of cutting length on rooting percentage of $M$. excelsa cutting was recorded, although there was a marked positive correlation between length and shoot production. Cutting length was

Table 4 The $t$-test result of on the comparison between air layering results from the branches that grow from coppices and twigs from the normal trees

\begin{tabular}{lcccccc}
\hline \multirow{2}{*}{ Parameters } & \multicolumn{2}{c}{$\begin{array}{c}\text { Levene's test for equality of } \\
\text { variances }\end{array}$} & \multicolumn{3}{c}{$T$-test for equality of means } \\
\cline { 2 - 8 } & $\mathrm{F}$ & Sig. & $\mathrm{T}$ & $\mathrm{Df}$ & Sig. (2-tailed) & Mean Difference \\
\cline { 2 - 8 } & 0.434 & 0.519 & 2.774 & 16 & 0.014 & 20,724 \\
\hline Percentage of life air layering & 0.603 & 0.449 & 1.388 & 16 & 0.184 & 11,112 \\
Percentage of rooted air layering & & & & &
\end{tabular}

Table 5 The correlation between shoot length and percentage of rooted air layering at eight month after treatment

\begin{tabular}{|c|c|c|c|c|c|}
\hline \multicolumn{2}{|c|}{ Parameter } & \multicolumn{2}{|c|}{ Coppices } & \multicolumn{2}{|c|}{ Normal trees } \\
\hline & & $\begin{array}{c}\text { Rooted air layering } \\
\qquad(\%)\end{array}$ & $\begin{array}{c}\text { Shoot length } \\
(\mathrm{cm})\end{array}$ & $\begin{array}{c}\text { Rooted air layering } \\
\qquad(\%)\end{array}$ & $\begin{array}{l}\text { Shoot length } \\
\text { (cm) }\end{array}$ \\
\hline \multirow[t]{3}{*}{ Rooted air layering (\%) } & Pearson Correlation & 1.00 & $0.766^{*}$ & 1.00 & 0.489 \\
\hline & Sig. (2-tailed) & & 0.016 & & 0.182 \\
\hline & $\mathrm{N}$ & 9 & 9 & 9 & 9 \\
\hline \multirow[t]{3}{*}{ Shoot length (cm) } & Pearson Correlation & $0.766^{*}$ & 1.00 & 0.489 & 1.000 \\
\hline & Sig. (2-tailed) & 0.016 & & 0.182 & \\
\hline & $\mathrm{N}$ & 9 & 9 & 9 & 9 \\
\hline
\end{tabular}

*. Correlation is significant at the 0.05 level (2-tailed). 
negatively correlated with foliar relative water content. Yang et al. (2015) reported that the cutting size both diameter and length as well as their interaction affected the rooting ability of norway spruce cuttings. The thicker and the longer cutting materials obtained better rooting. However, the interaction between cutting length and cutting diameter should be take into consideration. When the cutting diameter was greater than or less than a certain value, rooting decreased with increasing length.

Tchoundjeu and Leakey (1996) reported that the more number of nodes that will increase the cutting length and number of leaves will also directly increase the risk of mortaliity due to water stress by increasing transpiration rate. Furthermore, Yang et al. (2015) argued that an equilibrium between photosynthesis and transpiration and the rate of water and nutrient transport are important factors influencing rooting on cutting propagation. The modest size usually has more beneficial to rooting success.

\section{Conclusion}

The result of research revealed that three parameters of air layering which was taken from coppices are highly significant different. Those parameters are shoot length and shoot number as well as percentage of rooted air layering. Meanwhile, only two parameters of air layering which was taken from normal trees are significantly different, namely shoot number and percentage of rooted air layering. Overall results for air layering which was taken from coppices revealed that $1,000 \mathrm{ppm}$ of IBA obtained the best results compared to other treatments. The most interesting result on air layering of branches taken from coppice is that without any additional growth regulator to the air layering propagation is also still possible. While, air layering which was taken from normal trees revealed that the best treatment is 3,000 ppm of IBA. The result of experiment shows that the IBA seems to be more effective in regulating growth and rooting of E. zwageri air layering for both air layering resources compared to IAA.

\section{Recommendation}

Based on the research results, it is recommended to use $1,000 \mathrm{ppm}$ of IBA for promoting root system on air layering which was taken from coppices while using 3,000 ppm of IBA for air layering which was taken from normal adult trees.

\section{Acknowledgements}

We would like to show gratitude to Head of Environmental Agency, Batanghari District. We thank the following people Muhammar Prayogi, Adi Karta, and Ibnu Mubarak for helping the field works. The study was funded by Non-Tax Revenue, Forestry Faculty, University of Jambi, 2018.

\section{References}

Ajizah, A., Thihana, \& Mirhanuddin. (2007). Potensi ekstrak kayu ulin (Eusideroxylon zwageri T. et B.) dalam menghambat pertumbuhan bakteri Staphylococcus aureus secara in vitro. Bioscientiae, 4, 37-42.

Al-Sagri, F., \& Alderson, P. G. (1996). Effects of IBA, cutting type and rooting media on rooting of Rosa centifolia. Journal of Horticultural Science, 71(5), 729-737. https://doi.org/10.1080/14620316.1996.11515453

Aminah, H., Dick, J. M., \& Grace, J. (1997). Rooting of Shorea leprosula stem cuttings decreases with increasing leaf area. Forest Ecology and Management, 91(2), 247-254. https://doi.org/10.1016/S0378-1127(96) 03857-1

Beekman, H. A. J. M. (1949). Houtteelt in Indonesie (Silviculture in Indonesia). Wegeningen: Publicate van de Stichting`Fonds Landbouw Exportbureaue`19161918.

Bolstad, J. M., \& Libby, W. J. (1982). Comparison of radiata pine cuttings of hedge and tree-form after seven seasons. Silvae Genetica, 31, 9-13.

Ceulemans, R. J., Saugier, B. (1991). Photosynthesis. In A. S. Raghavendra (Ed.), Physiology of tree. New York: John Wiley and Sons, Inc.

Danu, Subiakto, A., \& Putri, K. P. (2011). Uji setek pucuk damar (Agathis loranthifolia Salisb.) pada berbagai media dan zat pengatur tumbuh. Jurnal Penelitian Hutan dan Konservasi Alam, 8(3), 245-252. https://doi.org/ 10.20886/jphka.2011.8.3.245-252

Diantina, M. (2008). Penggunaan zat pengatur tumbuh (ZPT) dan perbedaan tinggi cangkokan untuk mempercepat induksi akar ulin (Eusideroxylon zwageri Teijsm. \& Binn.). [undergraduate thesis]. Bogor: IPB University.

Gomez, K. A., \& Gomez, A. A. (1984). Statistical procedures for agricultural research. New York: John Wiley and Sons, Inc.

Gresser, E. (1919). Bijdragen resumeerend repport over het voorkomen van ijzerhout op de olieterreinen Djambi I. Tectona, 12, 283-304.

Hari, P., Nikinmaa, E., \& Korpilahti, E. (1991). Modeling: canopy, photosynthesis and growth. In A. S. Raghavendra (Ed.), Physiology of tree. New York: John Wiley and Sons, Inc.

Heyne, K. (1927). De Nuttige Planten van Nederlandsch Indie II. Buitenzorg: Departement van Landbouw, Nijverheid en Handel.

Hendromono, Sakai, C., Yamamoto, Y., Prameswari, D., \& Masano. (1996). Stek batang tiga jenis meranti dari ranting pohon dan anakan permudaan alam. Forest Research Bulletin, 599, 33-38.

Irawan, B. (1999). The effects of indoleacetic acid (IAA) and indolebutyric acid (IBA) on rooting and growth of bulian (Eusideroxylon zwageri T. et B.) cuttings. [thesis]. Gottingen: Forest Botany Institute Göttingen University.

Irawan, B. (2001). Conservation of ironwood (Eusideroxylon zwageri Teijsm. \&B inn.) through cutting propagation using indoleacetic icid (IAA) and indolebutyric icid 
(IBA). Tropenlandwirt, 73, 255-263.

Irawan, B. (2002). Ironwood (Eusideroxylon zwageri T.et $B$.): Present conditions and future development in Jambi, Indonesia. In R. Birner, D. R. Nurrochmat, \& S. Rosyadi (Eds.), Sustainable development: Socio-economic and environmental problems. Göettingen: Cuvillier Verlag.

Irawan, B. (2005). Ironwood (Eusideroxylon zwageri Teijsm.\& Binn.) and its varieties in Jambi, Indonesia. Göttingen: CuvillierVerlag.

Irawan, B. (2018). Bulian (Eusideroxylon zwageri Teijsm \& Binn.), Kayu Besi Borneo dan Sumatera. Bogor: IPB Press.

Irawan, B., \& Gruber, F. (2004). The importance of sprouting ability in conservation and development of ironwood (Eusideroxylon zwageri Teijsm \& Binn.). Paper presented at the International Seminar Deutscher Tropentag Berlin, Germany.

Irawan, B., Zuhdi, M., \& Fazriyas. (2011). Perbanyakan empat varietas bulian (Eusideroxylon zwageri Teijsm. \& Binn.) secara setek. Laporan Penelitian Hibah Bersaing Perguruan Tinggi. Jambi: Universitas Jambi.

[IUCN] International Union for Conservation of Nature. (2019). The 2000 IUCN list of threatened species. Retrieved from http://www.redlist.org/

Kammesheidt, L. (1998). The role of tree sprouts in the restoration of stand structure and species diversity in tropical moist forest after slash-and burn agriculture in Eastern Paraguay. Plant Ecology, 139, 155-165.

Kirschbaum, M. U. F. (2011). Does enhanced photosynthesis enhance growth? Lessons learned from $\mathrm{CO}_{2}$ enrichment studies. Plant Physiology, 155, 117-124. https://doi.org/10.1104/pp.110.166819

Kiyono, Y., \& Hastaniah. (2000). Growth of Eusideroxylon zwageri seedlings and silvicultural changes in loggedover and burned forests of bukit Soeharto, East Kalimantan, Indonesia. Japan Agricultural Research Quarterly, 34(1).

Kleinschmit, J., \& Svolba, J. (1988). The clonal option; current status and future development. Paper presented at the Meeting IUFRO WP Norway Spruce Provenance and Breeding. Tjörnarp/Sweden.

Koopman, M. J. F., \& Verhoef, L. (1938). Eusideroxylon zwageri, The ironwood of Borneo and Sumatera. Tectona, 31, 381-399.

Kostermans, A. J. H. (1957). Lauraceae. Communication of the Forest Research Institute. Indonesia No. 57. Bogor: Balai Besar Penjelidikan Kehutanan.

Kostermans, A. J. H., Sunarno, B., Martawijaya, A., \& Sudo, S. (1994). Eusideroxylon zwageri Teisjm. and Binnend.
In I. Soerianegara, \& R. H. M. J. Lemmens (Eds.), Plant resources of South-East Asia 5(1). Timber trees: major commercial timbers. Bogor: PROSEA.

Masano, R., \& Omon, M. (1983). Observation on natural regeneration of Eusideroxylon zwageri T. et B. in Senami forest complex, Jambi. Laporan Balai Penelitian Hutan No. 410. Bogor: Pusat Penelitian dan Pengembangan Kehutanan.

Miura, M., \& Yamamoto, S. (2003). Structure and dynamics of a Castanopsis cuspidata var. Sieboldii population in an old-growth, evergreen, broadleaved forest: The importance of sprout regeneration. Ecological Research, 18, 115-129. https://doi.org/10.1046/j.1440-1703. 2003.00540.x

Mulyani, N., Kusmana, C., \& Supriyanto. (1999). Study on propagation technique application of Rhizophora mucronata using hypocotyl cutting system. Jurnal Manajemen Hutan Tropika, 5(1), 57-65.

Nuraini, D., Irawan, B., \& Anggraini, R. (2017). Pengujian konsentrasi indole acetic acid (IAA) dan metode pengupasan kambium terhadap keberhasilan cangkok bulian (Eusideroxylon zwageri Teijsm. \& Binn.). [undergraduate thesis]. Fakultas Kehutanan Universitas Jambi.

Ofori, D., Newton, A. C., Leakey, R. R. B., \& Grace, J. (1997). Vegetative propagation of Milicia excelsa by leafy stem cuttings: Effects of maturation, coppicing, cutting length and position on rooting ability. Journal of Tropical Forest Science, 10(1), 115-129.

Oldfield, S., Lusty, C., \& Kinven, A. M. (1998). The world list of threatened trees. Cambridge: World Conservation Press.

Partomihardjo, T. (1987). The ulin wood which is threatened to extinction. Duta Rimba, 87-88(13), 10-15. https://doi.org/10.1016/0165-4896(87)90064-3

Peluso, N. L. (1992). The ironwood problem: (mis) management and development of an extractive rainforest product. Conservation Biology, 6(2), 210-219. https://doi.org/10.1046/j.1523-1739.1992.620210.x

Putz, F. E., \& Brokaw, N. V. L. (1989). Sprouting of broken trees on Barro Colorado Island, Panama. Ecology, 70, 508-512. https://doi.org/10.2307/1937555

Robinson, R. (1995). Kandungan organik tumbuhan tinggi. Bandung: Penerbit ITB.

Soedibja, R. S. (1952). Penjelidikan tentang tumbuh dan ekologi kaju besi (Eusideroxylon zwageri T. et B.) di lingkungan hutan Semandai (Palembang). Rimba Indonesia, 1(5), 215-223.

Soerianegara, I. (1974). Ecological researches relevant to current silviculture problems. Coordinated study of 
lowland forest of Indonesia. Bogor: BIOTROP and IPB.

Tchoundjeu, Z., \& Leakey, R. (1996). Vegetative propagation of African mahogany: Effects of auxin, node position, leaf area and cutting length. New Forest, 11(2), 125-136. https://doi.org/10.1007/BF00033408

Utami, N. W., Hoesen, D. S. H., Witjaksono, \& Danu. (2005). Perbanyakan ulin (Eusideroxylon zwageri T. et B.) dengan biji dan setek. Berita Biologi, 7(4),199-206.

Wibowo, A., Na'iem, M., \& Suseno, O. H. (2000). Pengaruh berbagai hormon dan klon terhadap kemampuan berakar setek pucuk jati. Paper presented at the National Seminar on Status of Silviculture, Yogyakarta.

[WWF] World Wildlife Fund. (2001). Sumateran lowland forest. Retrived from $\mathrm{http}$ ://www.worldwildlife.org.

Yang, F. O., Wang, J, \& \& Li, Y. (2015). Effects of cutting size and exogenous hormone treatment on rooting of shoot cuttings in Norway spruce (Picea abies (L.) Karst.]. New Forests, 46, 91-105. https://doi.org/10.1007/s11056014-9449-1 